\title{
Biogas production using water hyacinths to meet collective energy needs in a sahelian country
}

\begin{abstract}
O. Almoustapha ${ }^{1}$, S. Kenfack ${ }^{2}$, and J. Millogo-Rasolodimby ${ }^{1}$
${ }^{1}$ Université de Ouagadougou, Unité de Formation et de Recherche en Sciences de la Vie et de la Terre (UFR/SVT), Laboratoire de biologie et d'écologie végétales, 03 BP 7021 Ouagadougou 03, Burkina Faso ${ }^{2}$ Centre Régional pour l'Eau Potable et l'Assainissement (CREPA), 03 BP 7112 Ouagadougou 03, Burkina Faso

Abstract. This paper presents a pilot project that investigates the possibility of producing biogas from a mixture of water hyacinth and fresh rumen residue - replacing firewood as a source of fuel - to meet the energy needs of a maternity facility in Niamey (Niger). The discontinuous-type installation (batch reactors) is made up of six digesters measuring $5 \mathrm{~m}^{3}$ each. The output during hot and cool seasons, $0.52 \mathrm{~m}^{3}$ and $0.29 \mathrm{~m}^{3}$ respectively of biogas per $\mathrm{m}^{3}$ of digester per day, has met the energy needs of the maternity facility, estimated at $8 \mathrm{~m}^{3}$ of biogas per day. The study revealed strong seasonal variations: output during the hot season is approximatively 1.8 times greater than it is during the cool season. Large quantities of water hyacinth, an invasive plant present in Niger since 1986, are manually harvested in aquatic environments. The project is run by a local NGO, the Groupe d'Initiative pour les Energies Renouvelables (GIER), and supported by UNICEF and the Niger Basin Authority. The duration of the project is 8 months.
\end{abstract}

Keywords. biogas, water hyacinth, discontinuous digester

\section{Introduction}

The presence of the water hyacinth (Eichhornia crassipes) was noted in Niger in 1986 in a hydro-agricultural area in Niamey (Garba, 1986). Ten years later, it carpeted sections of the river running through the cities along the riverbanks. Water hyacinths cause ecological and economic problems by impeding navigation and fishing activities, clogging irrigation systems and by creating a chronic shortage of dissolved oxygen harmful to the fauna and the flora (Seehausen et al., 1997; Malik, 2006). Perna and Burrows (2005) noted that the water hyacinth covers on water bodies reduce the gaseous exchanges that take place at the air/water interface and reduce the photosynthetic activity of submerged plants by hindering the penetration of the sun's rays.

The Convention on Biological Diversity, in its article 8 (h), recommends that each contracting party take measures to prevent the introduction of exotic species and to control or to eradicate those that threaten ecosystems, habitats or species. The efforts expended by states and target communities have not succeeded in eradicating the water hyacinth from Sahelian West Africa.

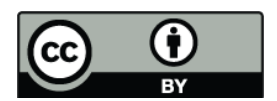

Correspondence to: O. Almoustapha (almoustapha1@yahoo.fr)
Experts in the field believe that it is difficult to eradicate the water hyacinth, since the conditions that allow it to proliferate are not being controlled (Howard and Matindi, 2003). Eutrophication and an average decrease of 40 to $60 \%$ in the flow of major rivers in West Africa - a result of global climate change - may be factors that contribute to the proliferation of the water hyacinth (UICN-BRAO et al., 2003).

In Niger, the actions taken have consisted in periodic hand weeding campaigns organized by municipal authorities and associations. The Groupe d'Initiative pour les Energies Renouvelables (GIER) participates in this initiative. Given the important amount of biomass drop from water during these campaigns, it seems worthwhile to investigate potential ways of valorising that biomass Experiments involving the use of water hyacinth for the production of biogas for cooking seemed to present a viable option in the context of Sahelian countries threatened by desertification. Indeed, biogas is an ecological fuel that may replace firewood.

The context in which member countries of the West African Monetary Union (WAMU) find themselves in is essentially rural and poor. The cost of petroleum products and electricity are very high considering the low level of economic activity. Therefore, the utilization of biomass to produce energy for modern use represents a good opportunity and a credible alternative (Arris et al., 2008). 
The international conference organized in Nairobi in May 2007, which was based on the theme Biogas for Better Life: An African Initiative (www.biogasafrica.org), expects to improve living conditions for women, children and the population in general by installing at least 20 million biogas facilities in the households of sub-Saharan Africa by the year 2020.

However, regardless of the stated intentions, it still seems necessary to document the issue in the context of Sahelian countries. The objectives of the project, which have been established by a local NGO called Groupe d'Initiative pour les Energies Renouvelables (GIER), are to:

- Evaluate the potential for biogas production using a combination of water hyacinth and fresh rumen residue to meet collective needs.

- Test the functioning of a discontinuous-type facility (batch reactors) in real-life conditions. The discontinuous procedure is simple: the digester is filled with solid substrates - usually lignocellulosic - inoculum and water, and then hermetically sealed until the production of biogas has ceased.

\section{Materials and methods}

\subsection{Experimentation site}

The biogas production pilot unit is located in Niamey (Latitude: $13^{\circ} 31 \mathrm{~N}$, Longitude: $2^{\circ} 26 \mathrm{E}$ ), the capital of Niger, in a health facility that specializes in providing support for pregnant women when they give birth (maternity).

\subsection{Water hyacinth supply}

At the peak of the water hyacinth's invasion, the ministry of environment established a national committee in response to its spread, which raised awareness and rallied both municipal populations and authorities. Riverside populations, fishing associations, NGOs, the army and several other volunteer organizations are invited to participate voluntarily in periodic campaigns of hand weeding. A portion of the hyacinths taken out of the water by people in canoes is loaded into vehicles and transported to the experimentation site.

\subsection{Experimental design}

Depending on the feeding mode and consistency of the substrate, three main types of digestion systems can be distinguished. Discontinuous digesters (batch), which are used in this case, use solid organic substrates (lignocellulosic) submerged in a slurry of bacteria and are then hermetically sealed until the production of biogas ceases. Continuous reactors are fed with liquid substrates providing a constant output (GRET, 1979). The semi-continuous fermenter (sequencing-batch reactor) falls midway between the first two.

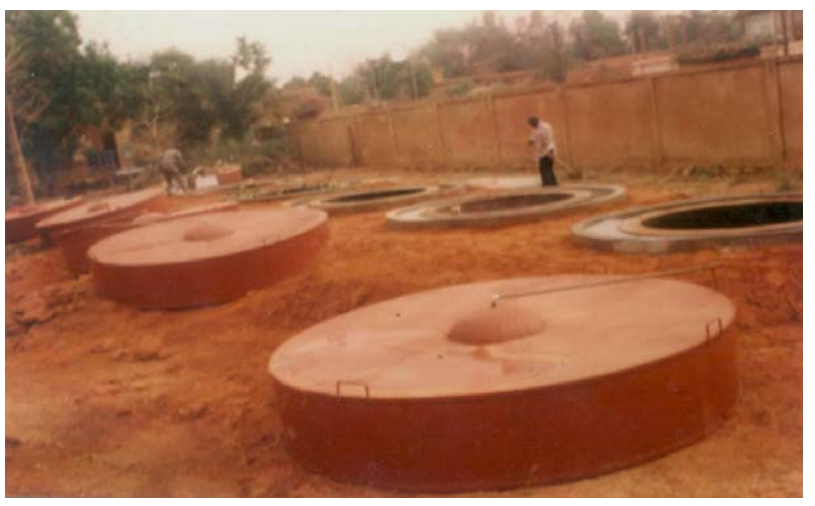

Figure 1. View of production digesters.

\subsubsection{Description}

The installation is made up of six discontinuous-type digesters and three storage gasometers (Fig. 1). The digesters, buried tanks made of reinforced concrete, measure $5 \mathrm{~m}^{3}$ and were designed to provide the anaerobic environment essential for the bacterial activity that produces the biogas. The gasometer covers and hoods are built with 20/10 black sheet metal.

\subsubsection{Sizing}

The sizing was based on an estimate of the average wood consumption of the maternity facility and on the biogas energy equivalent of the firewood traditionally used for cooking. Twenty kilograms of firewood are needed on a daily basis. Considering that 1 cubic meter $\left(1 \mathrm{~m}^{3}\right)$ of biogas under normal pressure is equivalent to $2.5 \mathrm{~kg}$ of firewood (Billaud and Varagnat, 1983, N'goran, 2006), $8 \mathrm{~m}^{3}$ of biogas are needed per day to meet the needs of the maternity facility.

\subsubsection{Experimental procedures}

Experiments were carried out during the cool season (20$\left.30^{\circ} \mathrm{C}\right)$ and the warm season $\left(30-40^{\circ} \mathrm{C}\right)$ and repeated three times. Three hundred kilograms dry weight of water hyacinth $(300 \mathrm{~kg})$, cut into small pieces of 5 to $10 \mathrm{~cm}$ pieces, and $1000 \mathrm{~kg}$ dry weight of fresh rumen residue (3/1 ratio) were diluted in $20 \mathrm{~m}^{3}$ of liquid and introduced into the digester. The metal cover that slides into the hydraulic joint hermetically seals the mixture. The gas is collected and stored in the gasometers. The volume of biogas is measured using an ELSTER HANDEL GMBH MAINZ volumetric meter, which has a limit of detection of less than $0.0010 \mathrm{~m}^{3}$. Gas pressure is measured with a hand-crafted pressure gauge made of a $10 \mathrm{~cm}^{2}$ section of plastic tube attached (in a U-shape) to a graduated rectangular plank (Figs. 2 and 3). One extremity of the tube containing water is connected to the digester while the other is left open. Gas pressure causes the column of water to move and its displacement indicates the amount of pressure being created. 


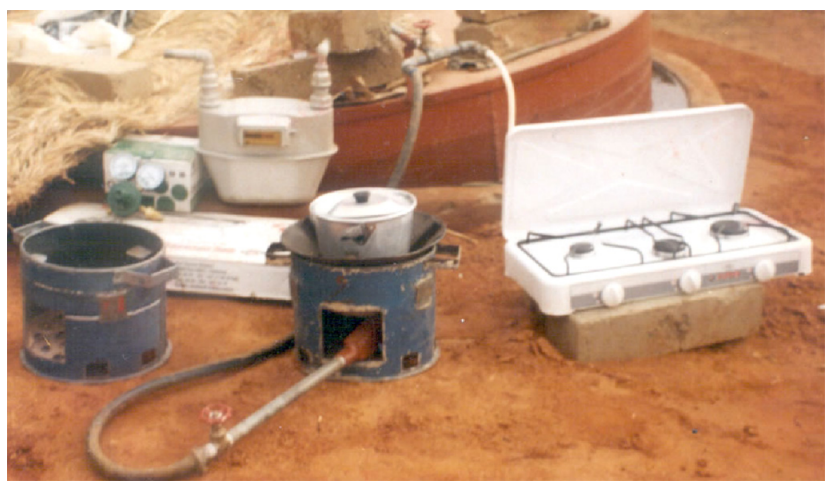

Figure 2. Biogas usage equipment.

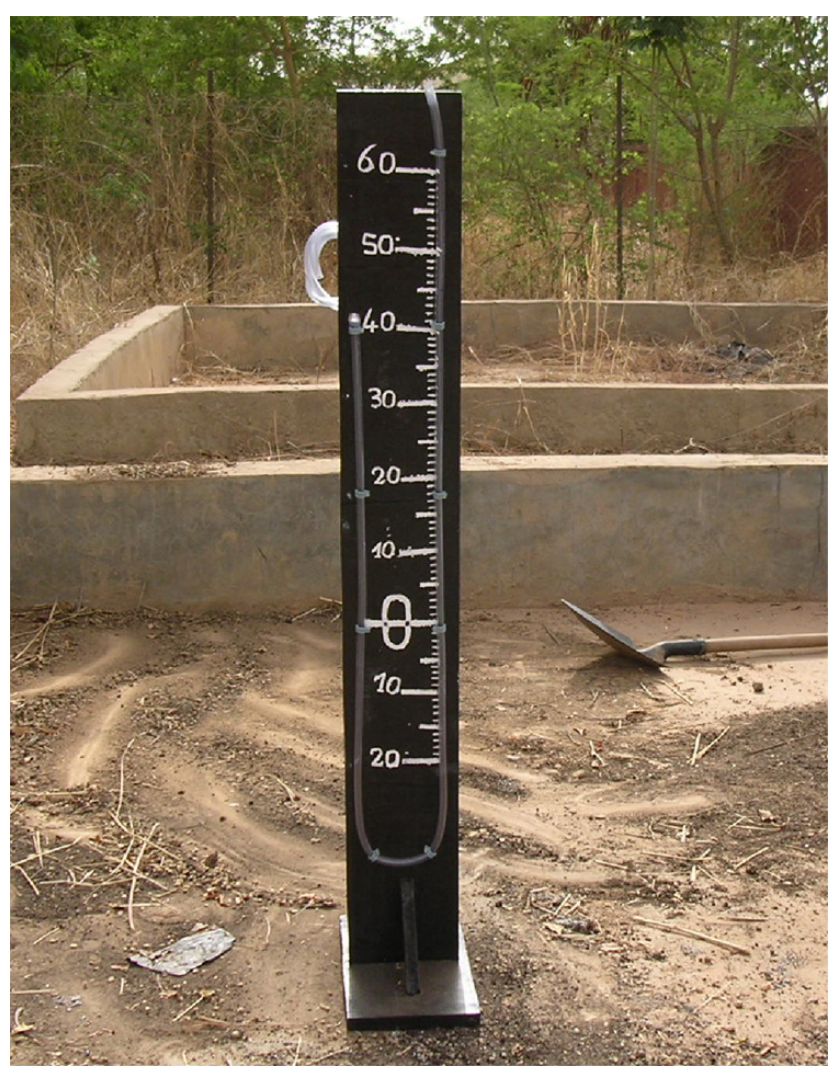

Figure 3. Hand-crafted pressure gauge.

\section{Results}

The study revealed that it is possible to produce biogas from a mixture of water hyacinth and fresh rumen residue. The simplicity of the operating procedures of discontinuous-type installations (batch reactors) is an advantage for popularizing its use. Biogas is a good quality fuel that can be used as a replacement for firewood and several other energy sources. The study's evaluation of production potential over a year revealed marked seasonal variations in biogas outflow.

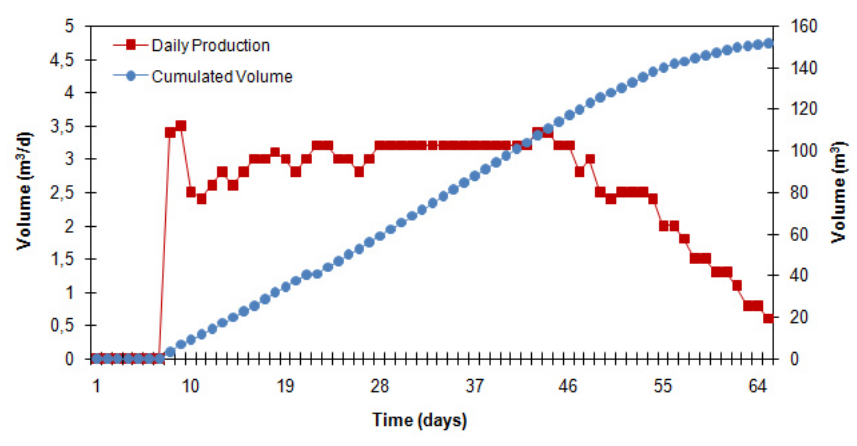

Figure 4. Kinetics and cumulative production of biogas during the warm season $\left(30-40^{\circ} \mathrm{C}\right)$.

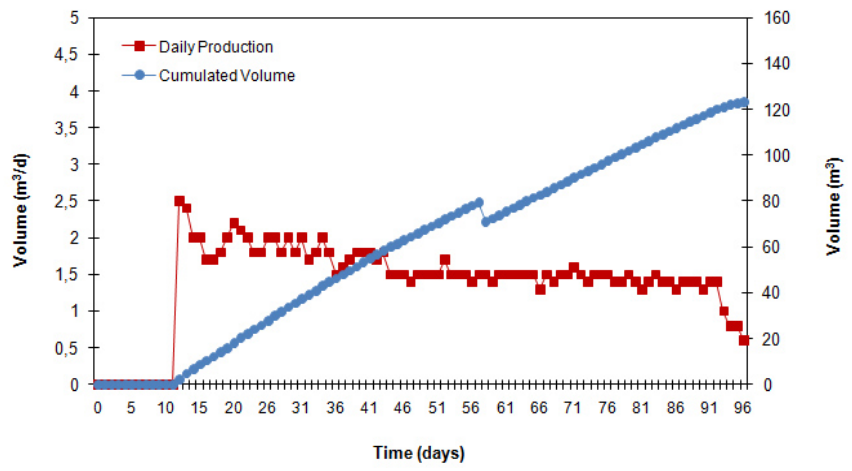

Figure 5. Kinetics and cumulative production of biogas during the cool season $\left(20-30^{\circ} \mathrm{C}\right)$.

\subsection{Biogas production during the dry, warm season $\left(30-40^{\circ} \mathrm{C}\right)$}

Figure 4 shows the kinetics of daily biogas production and the change in accumulated volume. Although biogas production began on day 8 , the gas became combustible only as of day 11. As of day 48, daily production began to decline steadily. The total volume of biogas produced after 65 days was $151.4 \mathrm{~m}^{3}$, that is, $2.6 \mathrm{~m}^{3} /$ day.

\subsection{Biogas production during the dry, cool season $\left(20-30^{\circ} \mathrm{C}\right)$}

Figure 5 shows the daily production and accumulated volume of biogas. The reaction began to take place on day 13. The biogas became combustible on day 18 . The total volume of biogas produced was $123.4 \mathrm{~m}^{3}$, that is, $1.48 \mathrm{~m}^{3} /$ day. Biogas production varies with time.

\section{Discussion}

The basic hypothesis of this study, which consists in exploring the possibility of producing biogas with water hyacinth and using it, instead of firewood for cooking, has been 
proven, as confirmed by certain authors (Chanakya et al., 1993; Kivaisi and Mtila, 1998; Singhal and Rai, 2003; Kumar, 2005). In this study, Biogas outflow is clearly related to seasonal variations in temperature. For the same retention time, the total volume of biogas obtained during the warm season is 1.8 times greater than that obtained during the cool season. However, the climate in Sahelian countries allows for year-round production of biogas with seasonal variations in flow rate.

\subsection{Practical implications}

\subsubsection{Facility output}

The output of the digesters - which are buried tanks made of reinforced concrete measuring $5 \mathrm{~m}^{3}$ - allows the functioning of the system to be assessed. The output, expressed in $\mathrm{m}^{3}$ of biogas per $\mathrm{m}^{3}$ of digester per day, has been calculated at 0.52 during the warm season and 0.29 during the cool season. The mean annual output of 0.41 , obtained in this study, can be compared to the results published by the Groupe de Recherche et d'Echange Technologique (Research and Technological Exchange Group) (GRET, 1979), which - despite the different results obtained - estimates the output of discontinuous systems to be 0.6. The output obtained in this study has been satisfactory, but can be improved by applying the appropriate pre-treatments (Ahring et al., 2001; Dearman and Bentham, 2006; Lu et al., 2007).

\subsubsection{Biogas utilization}

The biogas produced is intended to meet the needs of a maternity facility, estimated to be $20 \mathrm{~kg}$ of wood per day, or $8 \mathrm{~m}^{3}$ per day of biogas. The output obtained can meet the needs of the maternity whatever the season. Based on a ratio of dry matter content varying between 5 and $7 \%, 300 \mathrm{~kg} / \mathrm{dw}$ corresponds to approximately 5 tons of fresh biomass (Ganesh et al., 2005). Although the work involved is certainly exhausting, it will lead to a reduction in the river surface area covered by water hyacinth.

\subsubsection{Managing the facility}

The products obtained from the anaerobic digestion of lignocellulosic substrates are biogas and the compost that is removed from the digester at the end of the digestion process. The compost is an organic fertilizer having the appearance of farm manure and proven agronomical value.

In the case of biogas, a loading plan per group of three digesters was implemented during the warm season to reduce the costs of resupplying.

Revenue-generating activities should be organized to ensure that the expenses involved in operating the facility are covered. Every two months, a workforce has to be set up and canoes and vehicles rented in order to remove the water hyacinth from the river and to transport it to the experiment site. The purpose of the pilot project was also to explore how the facility could fall within the scope of local sustainable development plans. The following activities were chosen:

- The selling of compost and its use to establish nurseries for fruit trees and ornamental plants to be sold to provide funding for the water hyacinth supply.

- The organization of educational training activities using the facility as a teaching aid for environmental education. To be effective, the environmental education process must be able to bring attention to environmental problems, to explain the facts and to propose solutions.

\subsubsection{The constraints}

It must be noted that this is a one-time experimental pilot project, the results of which can help in the decision-making process. With this project, the main constraint, once the facility was set up, was to ensure that a constant supply of water hyacinth was maintained, as there was a transportation shortage.

Operation requirements become actual constraints only once they are brought into a given socio-economic environment. In terms of promoting biogas as a source of sustainable energy for small communities, a conscious commitment on the part of populations seems to be a determining factor.

It is essential that, the community should be directly involved, particularly women who have to carry out this new idea. In fact, women are commonly in charge of firewood issues in the sahelian community. It is important that they feel that the short, medium and long-term economic, ecological and social benefits will contribute to the reduction of poverty.

The costs of building and purchasing of peripheral equipment for the experimental pilot unit, which are entirely financed by the UNICEF representation in Niger, rose to 7366450 Francs CFA (11230 Euros at the given rates on 15 December 2008). Cost remains a limiting factor in the creation of this type of infrastructure that local artisans have the knowledge to develop.

In the Sahelian context, it would be sensible to focus on farms and agricultural co-operatives to spread the concept of biogas use for domestic and collective purposes. To promote the use of the water hyacinth, the supply constraints can be resolved by setting up the facility close to the raw material source and by including the project in the promotion of vegetable crops. The cost of firewood and the subsidies on butane gas - under the WAMU (West African Monetary Union) - which biogas should replace, also bear on the profitability of biogas facilities.

The use of biogas is an instrument to reduce greenhouse gas emissions. The Kyoto protocol contains international monetary mechanisms to provide an incentive for greenhouse gas reductions. Amongst those mechanisms a semi-column ecological taxes, financial incentives, emission quota and 
tradable permits, allow to reduce $\mathrm{CO}_{2}$ emissions at a lesser cost (Mariéthoz, 2000). In this context, the Clean Development Mechanism (CDM) allows developing countries to sell $\mathrm{CO}_{2}$ credits to industrialised countries subjected to emission targets under the Kyoto protocol. The CDM contributes to the reduction of $\mathrm{CO}_{2}$ emissions and to a financial influx and technology transfer to the benefit of developing countries (Mariéthoz, 2000).

\section{Conclusions}

The study has shown that discontinuous-type facilities are able to produce biogas from a mixture of water hyacinth and fresh rumen residue to meet collective needs in cooking energy. The facility's yield, reported in $\mathrm{m}^{3}$ of biogas per $\mathrm{m}^{3}$ of digester per day, has been 0.52 during the warm season and 0.29 during the cool season. Although the yields have been quite satisfactory, they can be improved by applying the appropriate pretreatments. The facility can save 7.3 tonnes of firewood per year. Promoting the use of biogas will contribute to the fight against desertification.

Using the water hyacinth as a substrate for the production of biogas is an advantageous control strategy because it permits a "productive fight" against the plant's invasion. The stock, which is available in a given space and time, is renewable, and all of the harvested plants are replenished within a growing season.

Issues involving the recovery of biomass energy and the decisions concerning the promotion of biogas technology in order to replace firewood should be discussed in the general framework of the economy of the sahelian countries. Finding a reliable alternative to the excessive use of firewood to fight desertification and restore soil fertility continues to pose a challenge that the promotion of methane fermentation technology might help resolve.

The creation of a biogas market, led by private contractors, will most likely contribute to the popularization of biogas technology for domestic purposes. The digester is just a small part of the whole system, which encompasses, on the one hand, the harvesting and processing of the raw material (water hyacinth, plant residues, organic urban waste, etc.) and on the other, the management of the finished products: biogas and organic fertilizer. Running parallel to this process, an artisan sector for the manufacturing and repairing of the equipment that utilizes biogas will probably emerge.

Successful popularisation of biogas is more than just a question of technological approaches focused on engineering. It must also be in line with a market dynamic towards which a "Clean Development Mechanism" (CDM) could assist in channelling the financial flow of carbon payments and technology transfer towards Africa.
Acknowledgements. The authors would like to thank the Groupe d'Initiave pour les Energies renouvelables (GIER), The Niger Basin Authority, which is attempting to control the spread of the water hyacinth, and the UNICEF representation in Niger, an organization concerned with the welfare of mothers and children, who participated in the financing of the project.

\section{References}

Ahring, B. K., Ibrahim, A. A., and Mladenovska, Z.: Effect of temperature increase from $55^{\circ} \mathrm{C}$ to $65^{\circ} \mathrm{C}$ on performance and microbial population dynamics of an anaerobic reactor treating cattle manure, Water Res., 35, 10, 2446-2452, 2001.

Arris, L., Lang, A., Spellman, J., and Tawney, L.: Bioenergy Report in UEMOA Member Countries, Ed. By United nations foundation and the Hub for Rural Development in West and Central Africa, 152 pp., available online: http://www.globalproblems-globalsolutions-files.org/gpgs_files/ pdf/UNF_Bioenergy/UNF_Bioenergy_full_report.pdf, 2008.

Billaud, V. and Varagnat, F.: Les dossiers du biogaz. Dossier A. Ministère des relations extérieures, Coopération et Développement, France, 72 pp., 1983.

Chanakya, H. N., Borgaonkar, S., Meena, G., and Jagadish, K. S.: Solid-phase biogas production with garbage or water hyacinth, Bioresour Technol., 46, 227-31, 1993.

Dearman, B., Marschner, P., and Bentham, R. H.: Methane production and microbial community structure in single-stage batch and sequential batch systems anaerobically co-digesting food waste and biosolids, Appl. Microbiol. Biot., 69(5), 589-596, 2006.

Ganesh, P. S., Ramasamy, E. V., Gajalakshmi, S., and Abassi, S. A.: Extraction of volatile fatty acids (VFAs) from water hyacinth using inexpensive contraptions, and the use of VFAs as feed supplement in conventional digesters with concomitant final disposal of water hyacinth as vermicompost, Biochem. Eng. J., 27, 17-23, 2005.

Garba, M.: La jacinthe d'eau colonise le fleuve Niger, Sahel Dimanche du 20 janvier 1986, 20 pp., 1986.

GRET: Biomasse: comparaison des valorisations des sous-produits agricoles, Coll. "Technologie et Développement" Ministères de la coopération, France, 300 pp., 1979.

Howard, G. W. and Matindi, S. W.: Les espèces étrangères envahissantes dans les zones humides de l'Afrique, UICN, GISP, RAMSAR, 15 pp., 2003.

Kivaisi, A. K. and Mtila, M.: Production of biogas from water hyacinth (Eichhornia crassipes) (Mart) (Solms) in a two-stage bioreactor, World J. Microb. Biot., 14, 125-131, 1998.

Kumar, S.: Studies on efficiencies of bio-gas production in anaerobic digesters using water hyacinth and night-soil alone as well as in combination, Asian J. Chem., 17, 934-938, 2005.

Lu, J., Gavala, H. N., Skiadas, I. V., Mladenovska, Z., and Ahring, B. K.: Improving anaerobic sewage sludge digestion by implementation of a hyper-thermophilic prehydrolysis step, J. Environ. Manage., 88, 4, 881-889, 2008.

Malik, A.: Environmental challenge vis a vis opportunity: The case of water hyacinth, Environ. Int., 33, 1, 122-138, 2007.

Mariéthoz, E.: Les enjeux et défis du XXIème siècle dans la perspective du développement durable, Centre Universitaire d'Ecologie Humaine et des Sciences de l'Environnement de l'Université de Genève (CUEH), 138 pp., 2000. 
N'goran, C.: Communautés Locales et Gestion Durable Des Energies en Afrique, Cas de la Côte d'Ivoire, SGP, UNOPS, UNDP 52 pp., 2006.

Perna, C. and Burrows, D.: Improved dissolved oxygen status following removal of exotic weed in important fish habitat lagons of the tropical Burdekin Riva floodplain, Australia, Mar. Pollut. Bull., 51, 138-148, 2005.

Seehausen, O., Witte, F., Katunzi, E. F., Smits, J., and Bouton, N.: Patterns ofthe remnant cichlid fauna in southern Lake Victoria, Conserv. Biol., 11, 890-904, 1997.
Singhal, V. and Rai, J. P.: Biogas production from water hyacinth and channel grass used for phytoremediation of industrial effluents, Bioresour. Technol., 86, 221-225, 2003

UICN-BRAO, GWP-WAWP, CILSS: Eau, changement climatique et désertification en Afrique de l'ouest: Stratégie régionale de préparation et d'adaptation, UICN-BRAO, GWP-WAWP, CILSS, 59 pp., 2003.

www.Biogasafrica.org, last access: 18 January 2009. 